\title{
Polarographic Study on the Reaction of Metal Ions with EDTA and Carboxylic Acids in N,N-Dimethylformamide
}

\author{
by \\ Su Chan Moon \\ Department of Chemistry, Faculty of Science, Kyoto University, Kyoto, Japan
}

(Received Feb. 24, 1971)

\begin{abstract}
Synopsis
The reactions of metal ions with various carboxylic acids including EDTA were investigated in DMF using the polarographic method. It was found that most of the metal ions form slightly soluble salts with EDTA before the formation of corresponding chelates; alkali metal ions react with EDTA in the ratio of $4: 1$, alkaline earth metal ions and other bivalent cations in the ratio of $4: 2$, and trivalent cations such as iron and indium ions in the ratio of $4: 3$. Most of the metal complexes of EDTA formed in DMF were found to be more stable than those in aqueous solutions. Therefore, in 100\% DMF these complexes, except complexes of iron(III), copper(II), rubidium (I) and cesium(I), showed no polarograpnic wave until the solvent was reduced. The behaviour of EDTA complexes in DMF were compared with that of the complexes formed with other carboxylic acids, such as oxalic, malonic, succinic, phthalic, acetic, benzoic and salicylic acids.
\end{abstract}

\section{Introduction}

It is well known that, in aqueous solutions, ethylenediaminetetraacetic acid (EDTA, $\mathrm{H}_{4} \mathrm{Y}$ ) forms stable chelates with most metal ions and is of very practical use in analytical chemistry. The chelates of alkali metal ions, however, are not analytically applicable due to their insufficient stabilities. This fact prompted the author to study the chelation of EDTA with alkali metal ions in $N, N$-dimethylformamide (DMF), which is aprotic and has lower dielectric constant than water. EDTA is a very weak acid in DMF and most metal ions are precipitated by forming salts or ion pairs with EDTA anion before the formation of corresponding chelates. The composition of the salts was determined by the amperometric technique. When excess EDTA anion is added, the precipitates are dissolved forming complexes; the stability constants of some metal complexes with EDTA were determined by the conventional polarographic method. The behaviour of EDTA anion to form salts with metal ions was compared with those of the anions of mono- and dibasic carboxylic acids, such as oxalic, malonic, succinic, phthalic, acetic, benzoic and salicylic acids. In this connection, the dissociation constants of these acid in DMF were also determined using the potentiometric method.

\section{Experimental}

Preparation of pure $N, N$-dimethylformamide: Nakarai reagent grade $N, N$-dimethylformamide (DMF) was shaken with potassium hydroxide pellets ${ }^{1)}$ (30 g/l of solvent) for

* Present Address : Department of Chemistry, College of Liberal Arts and Sciences, Pusan University, Jangjeon-dong, Tongre-ku, Pusan, Korea 
two hours, decanted, and after bubbling nitrogen gas for thirty minutes, shaken with phosphorous pentoxide ${ }^{2} \quad(20 \sim 30 \mathrm{~g} / l$ of solvent $)$ for two hours. After decanting, the solvent was distilled at $50 \sim 60^{\circ} \mathrm{C}$ under reduced pressure $(15 \sim 20 \mathrm{mmHg})$ with a $25 \times$ $650 \mathrm{~mm}$ adiabatic vacuum fractional distillation column filled with Dixon packing. A fraction of about $70 \%$ was collected. The concentration of basic impurities in freshly purified solvent as estimated spectrophotometrically at $400 \mathrm{~m} \mu$ upon addition of $p$-nitrophenol was $\leq 1 \times 10^{-5} \mathrm{M}$, the water contents by Karl Fisher titration was $\leq 0.005$ $\mathrm{M}$, and the specific conductance was $7 \sim 20 \times 10^{-8} \mathrm{ohm}^{-1} \mathrm{~cm}^{-1}$.

Preparation of tetraethylammonium ethylenediaminetetraacetate: Tetraksi (tetraethylammonium) ethylenediaminetetraacetate $\left(\mathrm{Et}_{4} \mathrm{~N}\right)_{4} \mathrm{Y}$ ) was prepared by adding EDTA to the aqueous tetraethylammonium hydroxide solution up to the molar ratio of $1: 4$, then evaporated to a syruppy state by a rotary evaporator at $70 \sim 80^{\circ} \mathrm{C}$. This was treated with a small portion of pure benzene-DMF mixture, then evaporated to dryness. The procedure was repeated three times after adding pure benzene and recrystallized from the same mixed solvent, and dried at $50 \sim 70^{\circ} \mathrm{C}$ under reduced pressure on phosphorous pentoxide. This salt is white and very hygroscopic, and changes yellow slowly, but when kept in benzene-DMF mixture it is fairly stable.

Bis(tetraethylammonium) dihydroethylenediaminetetraacetate $\left(\left(\mathrm{Et}_{4} \mathrm{~N}\right)_{2} \mathrm{H}_{2} \mathrm{Y}\right)$ was prepared by adding EDTA to the aqueous tetraethylammonium hydroxide solution up to the molar ratio of $1: 2$ and treated similarly as before. Their concentrations in DMF solutions were determined by potentiometric titration with picric acid in DMF, or by chelatometric titration with an aqueous zinc standard solution.

Preparation of other tetraethylammonium salts: Tetraethylammonium oxalate, malonate, succinate, phthalate, acetate, benzoate and salicylate were prepared by neutralizing the corresponding acid with tetraethylammonium hydroxide solution after dissolving the acid in a 50\% ethanol. Phenolphthalein served as an external indicator. The resulting solutions were evaporated to a syruppy state in the rotary evaporator at $70 \sim 80^{\circ} \mathrm{C}$ and the residues, except the acetate, recrystallized from the benzene-DMF mixture and dried at $50 \sim 70^{\circ} \mathrm{C}$ under reduced pressure. The acetate was treated repeatedly with benzene-ethanol mixture and recrystallized. The DMF solutions of these salts were titrated with picric acid potentiometrically to determine the concentrations.

Preparation of unhydrous metal perchlorates: All metal salts used for the study were the perchlorates. Alkali and alkaline earth perchlorates were recrystallized from their aqueous solutions and dried at $180 \sim 200^{\circ} \mathrm{C}$ under reduced pressure at $5 \sim 9 \mathrm{mmHg}$ on phosphorous pentoxide for $24 \mathrm{hrs}$. Other perchlorates were prepared by reacting the sulfates with barium perchlorate, or the hydroxides or carbonates with perchloric acid. From these solutions the perchlorates were crystallized as the hydrates and then dried at $110^{\circ} \mathrm{C}$ in the oven. The dried hydrates were dissolved in DMF to saturation, then azeotropically distilled twice with dry benzene and crystallized. These were dissolved in fresh DMF before measurement and the concentrations were determined by chelatometry with an aqueous EDTA standard solution.

Polarograph: Polarograms at the dropping mercury electrode were recorded with a three-electrode polarograph, Yanagimoto P8-DP, and an aqueous saturated calomel electrode (S. C. E.) served as the reference. The reproducibility of the junction potential in this experiment was within $\pm 10 \mathrm{mV}$. 
pH measurement: A Yanagimoto Model $\mathrm{pH}-7 \mathrm{pH}$ meter with a millivolt scale, and a Horiba No. 1026 glass electrode were used. The reference half cell was an aqueous S.C.E. with a salt bridge similar to the one used by Takaoka ${ }^{4}$. The glass electrode, when not in use, was stored in DMF containing $0.005 \mathrm{M}$ tetraethylammonium perchlorate and picric acid, and it was calibrated with a dilute solution of picric acid ${ }^{5)}$ and the buffer solution of salicylic acid and its tetraethylammonium salt before and after each measurement. The cell for E.M.F. measurement was an H-type cell. The tip of the reference half cell was dipped in the compartment containing $0.005 \mathrm{M}$ tetraethylammonium perchlorate, and the other compartment was filled with the test solution. For the determination of acid dissociation constants, $10 \mathrm{ml}$ of the tetraethylammonium salt solution of the acid in question was placed into the glass electrode compartment, and titrated with the acid or a freshly prepared picric acid solution. All measurements were carried out under a nitrogen atmosphere at $25 \pm 1{ }^{\circ} \mathrm{C}$.

\section{Results and Discussion}

It was found that pure unhydrous DMF dissolved EDTA to form approximately $4 \times 10^{-4} \mathrm{M}$ solution at $25^{\circ} \mathrm{C}$; the solubility is much less than that reported by Yosimura et $\left.a l^{6}\right)(7 \mathrm{~g} \mathrm{EDTA} / 100 \mathrm{~g} \mathrm{DMF}$, ca $0.24 \mathrm{M})$. The alkali metal salts of EDTA were even less soluble than EDTA itself. Therefore, these could not be used as chelating reagents in the present investigation. Tetraethylammonium salts of EDTA seemed to be hopeful because of higher solubility in DMF; the solubility of bis(tetraethylammonium) dihydroethylenediaminetetraacetate $\left(\left(\mathrm{Et}_{4} \mathrm{~N}\right)_{2} \mathrm{H}_{2} \mathrm{Y}\right)$ at $25^{\circ} \mathrm{C}$ was determined as $7.1 \times 10^{-2}$ $\mathrm{M}$ and that of tetrakis(tetraethylammonium)ethylenediaminetetraacetate $\left(\left(\mathrm{Et}_{4} \mathrm{~N}\right)_{4} \mathrm{Y}\right)$ as $7.9 \times 10^{-2} \mathrm{M}$. However, the use of $\left(\mathrm{Et}_{4} \mathrm{~N}\right)_{2} \mathrm{H}_{2} \mathrm{Y}$ as a chelating reagent was found to be inadequate because protons are liberated by the following reactions;

$$
\begin{aligned}
& 4 \mathrm{Na}^{+}+\mathrm{H}_{2} \mathrm{Y}=\rightleftharpoons \mathrm{Na}_{4} \mathrm{Y}+2 \mathrm{H}^{+} \\
& 2 \mathrm{Mg}^{++}+\mathrm{H}_{2} \mathrm{Y}=\rightleftharpoons \mathrm{Mg}_{2} \mathrm{Y}+2 \mathrm{H}^{+}
\end{aligned}
$$

The protons thus liberated give a reduction wave at $c a .-2.0 \mathrm{~V} v s$. aq. S.C.E. and interfere with the polarographic investigation. Therefore, the $\left(\mathrm{Et}_{4} \mathrm{~N}\right)_{4} \mathrm{Y}$ was used throughout this work.

Reaction of metal ions with $\left(E t_{4} N\right)_{4} Y$ : The dissociation constants of EDTA in DMF were determined potentiometrically by titrating the solution of $\left(\mathrm{Et}_{4} \mathrm{~N}\right)_{4} \mathrm{Y}$ with picric acid and the results are tabulated in Table 1. In aqueous solutions, the values

Table 1. Dissociation constants of EDTA and carboxylic acids in DMF.

\begin{tabular}{l|r|r|r|r}
\hline \multicolumn{1}{c|}{ Acid } & $\mathrm{pK}_{1}$ & $\mathrm{pK}_{2}$ & $\mathrm{pK}_{3}$ & $\mathrm{pK}_{4}$ \\
\hline EDTA & 8.69 & 10.45 & 18.5 & 21.1 \\
Oxalic & 7.02 & 18.3 & & \\
Malonic & 7.35 & 20.7 & & \\
Succinic & 10.05 & 19.2 & & \\
Phthalic & 7.06 & 20.2 & & \\
Acetic & 13.82 & & & \\
Benzoic & 12.35 & & & \\
Salicylic & 8.28 & & & \\
\hline
\end{tabular}


of $\mathrm{pK}_{1}, \mathrm{pK}_{2}, \mathrm{pK}_{3}$ and $\mathrm{pK}_{4}$ have been reported to be $1.99,2.67,6.16$ and 10.26, respectively. Therefore, EDTA in DMF is a much weaker acid than in aqueous solutions.

When alkali metal ions in DMF-0.1 M Et ${ }_{4} \mathrm{NClO}_{4}$ solution are titrated with a solution of $\left(\mathrm{Et}_{4} \mathrm{~N}\right)_{4} \mathrm{Y}$, the polarographic reduction waves of these ions decrease their heights as shown in Figs. 1 and 2, and precipitates are formed in the cell. From the titration curves, it is apparent that four alkali metal ions are combined with one EDTA anion to form salts $\left(\mathrm{M}_{4} \mathrm{Y}\right)$. When excess $\left(\mathrm{Et}_{4} \mathrm{~N}\right)_{4} \mathrm{Y}$ is added, however, the precipitates are dissolved again and, in the cases of rubidium(I) and cesium(I), new waves appear at more negative potentials than the original waves (Fig. 2). The heights of the new waves increase with the increase of $\left(\mathrm{Et}_{4} \mathrm{~N}\right)_{4} \mathrm{Y}$ added and reach a constant value when the molar ratio of $\left(\mathrm{Et}_{4} \mathrm{~N}\right)_{4} \mathrm{Y}$ to alkali metal ions becomes larger than unity. This seems
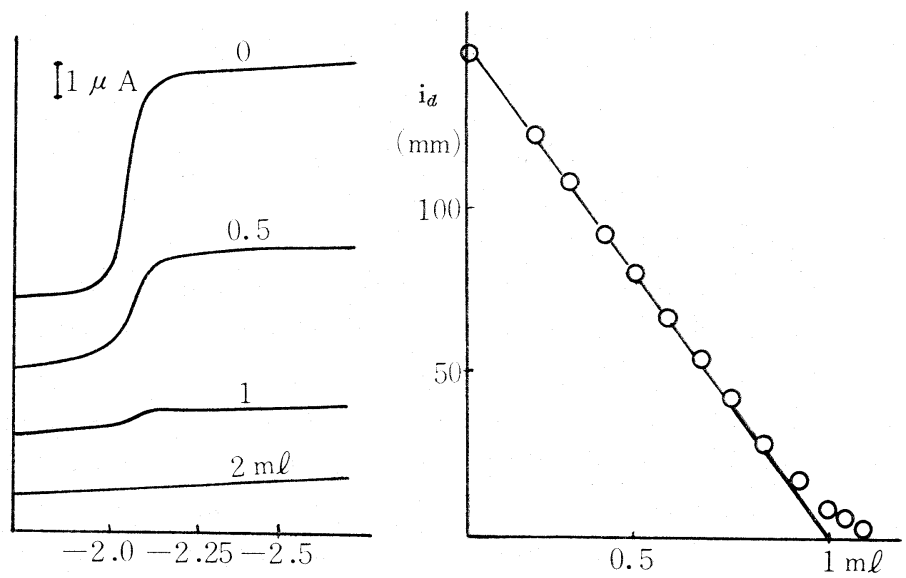

Volt vs S. C.E

Fig. 1. Polarograms and an amperometric titration curve of $\mathrm{Na}^{+}$in DMF. $10 \mathrm{ml}$ of $0.004 \mathrm{M} \mathrm{Na}+$ containing $0.1 \mathrm{M} \mathrm{Et}_{4} \mathrm{NClO}_{4}$ was titrated with $0.01 M\left(\mathrm{Et}_{4} \mathrm{~N}\right)_{4} \mathrm{Y}$ solution.
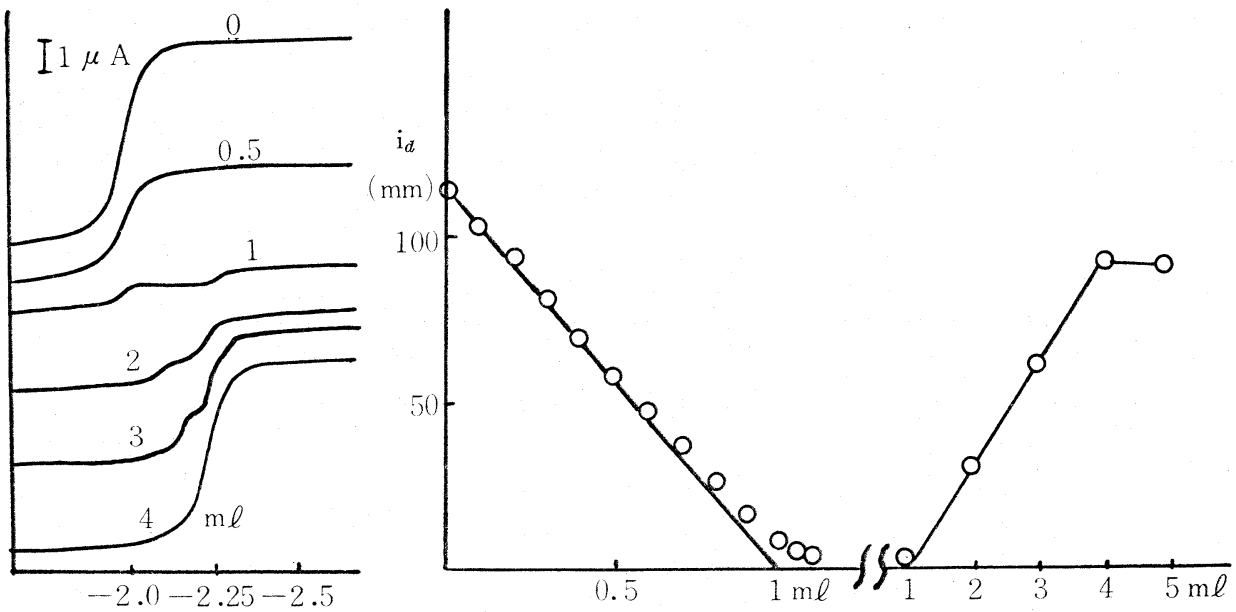

volt vs S.C.E

Fig. 2. Polarograms and an amperometric titration curve of $\mathrm{Cs}^{+}$in $\mathrm{DMF}$.

$10 \mathrm{ml}$ of $0.004 M \mathrm{Cs}^{+}$containing $0.1 M \mathrm{Et}_{4} \mathrm{NGlO}_{4}$ was titrated with $0.01 M\left(\mathrm{Et}_{4} \mathrm{~N}\right)_{4} \mathrm{Y}$ solution. 
to show that the final products are one-to-one complexes or chelates. The formation constants of the complexes, determined by the conventional method ${ }^{7)}$, are $10^{7.5}$ for $\mathrm{Rb}^{+}$ and $10^{7.1}$ for $\mathrm{Cs}^{+}$. With other alkali metal ions the reduction waves do not reappear even after the addition of excess $\left(\mathrm{Et}_{4} \mathrm{~N}\right)_{4} \mathrm{Y}$, probably because of the higher stabilities of the formed complexes.

Similar titration curves are obtained in the amperometric titrations of alkaline earth and other bivalent metal ions with EDTA anion (Fig. 3). In these cases, two metal ions are combined with one EDTA anion forming precipitates of $M_{2} Y$ salts. The addition of excess $\left(\mathrm{Et}_{4} \mathrm{~N}\right)_{4} \mathrm{Y}$ dissolves the precipitates but it does not give new wave as in the case of sodium ion. Exceptionally, $\mathrm{Cu}(\mathrm{II})$ ion gives cathodic wave which is fairly

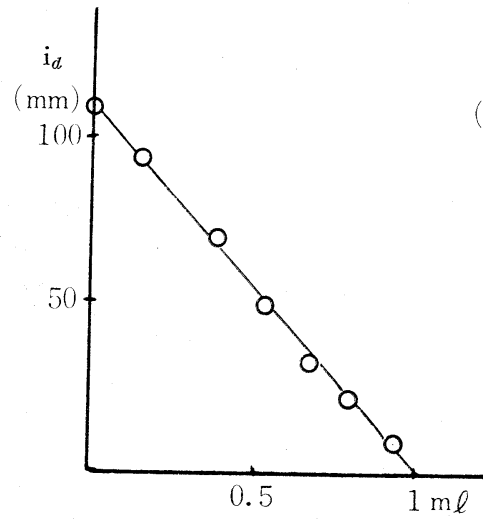

(A)

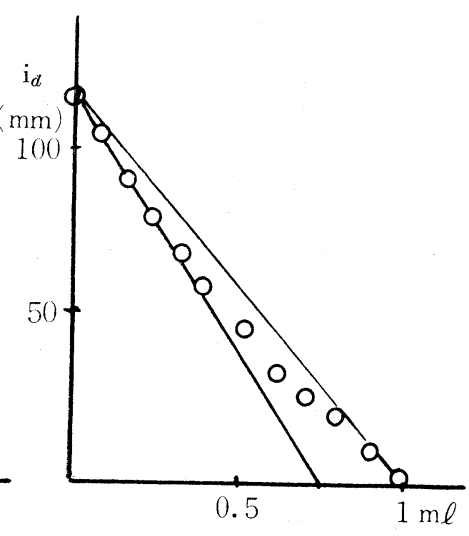

(B)

Fig. 3. Amperometric titration curves in DMF.

(A) : $10 \mathrm{ml}$ of $0.002 M \mathrm{~Pb}^{++}$containing $0.1 \mathrm{M} \mathrm{Et}_{4} \mathrm{NGlO}_{4}$ was titrated with $0.01 M\left(\mathrm{Et}_{4} \mathrm{~N}\right)_{4} \mathrm{Y}$ solution.

(B) : $10 \mathrm{ml}$ of $0.001 M \mathrm{In}^{+++}$containing $0.1 M \mathrm{Et}_{4} \mathrm{NGlO}_{4}$ was titrated with $0.01 M\left(\mathrm{Et}_{4} \mathrm{~N}\right)_{4} \mathrm{Y}$ solution.

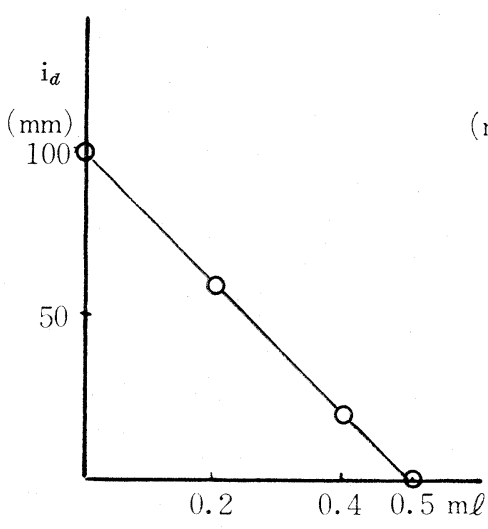

(A)

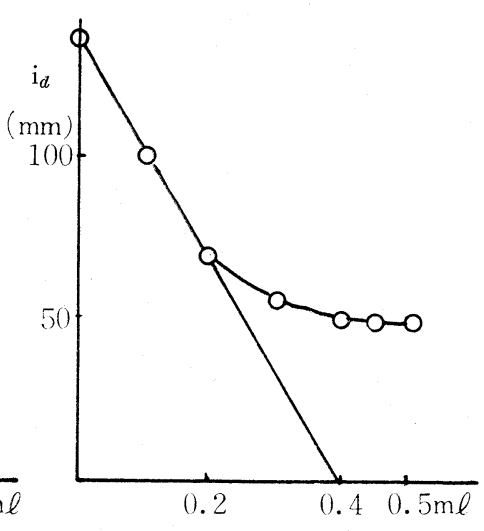

(B)

Fig. 4. Amperometric titration curves in DMF.

(A) : $10 \mathrm{ml}$ of $0.0025 M \mathrm{~Pb}^{++}$containing $0.1 M \mathrm{Et}_{4} \mathrm{NClO}_{4}$ was titrated with $0.05 M\left(\mathrm{Et}_{4} \mathrm{~N}\right)_{2} \mathrm{PbY}$ solution.

(B) : $10 \mathrm{ml}$ of $0.004 M \mathrm{Na}^{+}$containing $0.1 M \mathrm{Et}_{4} \mathrm{NClO}_{4}$ was titrated with $0.05 M\left(\mathrm{Et}_{4} \mathrm{~N}\right)_{2} \mathrm{PbY}$ solution. 
complicated and ill-defined.

In Fig. 3B the titration curve of In(III) with EDTA anion is shown. In the initial part, the curve has a slope corresponding to the formation of $M_{4} Y_{3}$ salt, but it deviates gradually from the slope and at the end of the titration indicates the formation of one-to-one complex (or chelate).

The reactivity of $\mathrm{PbY}^{=}$ion was tested by amperometric titrations of $\mathrm{Pb}^{++}$and $\mathrm{Na}^{+}$ions with a solution of $\left(\mathrm{Et}_{4} \mathrm{~N}\right)_{2} \mathrm{PbY}$. The $\mathrm{PbY}=$ ion reacts with $\mathrm{Pb}^{++}$quantitatively to form $\mathrm{Pb}_{2} \mathrm{Y}$, but with $\mathrm{Na}^{+}$only a part of it reacts to form $\mathrm{Na}_{2} \mathrm{PbY}$ (Fig. 4).

Reactions of metal ions with other carboxylic acid: Table 1 shows the results of potentiometric determinations of dissociation constants of several carboxylic acids in DMF. The reactions of tetraethylammonium salts of these acids with alakli metal ions were investigated by amperometric titration. The anions of dicarboxylic dibasic acids such as oxalate, malonate, succinate and phthalate are combined almost quantitatively in the ratio of $1: 2$ with alkali metal ions and precipitated. The precipitates are insoluble even after the addition of excess acid anions.

The reactions of acetate, benzoate and salicylate with alkali metal ions are not quantitative. The decrease of the wave heights and the shift of the half-wave potentials were both slight, except in higher concentrations where precipitation occurred (the solubility of sodium acetate in DMF was measured and found to be $1.1 \times 10^{-3} \mathrm{M}$ at $25 \pm$ $0.1^{\circ} \mathrm{C}$ ). The polarograms of bivalent metal ions, on the other hand, were strongly influenced by these acid anions as shown in Table 2. The half-wave potential of $\mathrm{Cd}^{++}$ in $\mathrm{DMF}$ shifted from $-0.57 \mathrm{~V}$ to $-1.73 \mathrm{~V}$ by adding equivalent amount of acetate ion, and the wave remained at the same potential even when much more acetate ion was added. Because of the irreversibility of the wave the stability constants cannot be calculated.

In conclusion, the anions of EDTA and dibasic carboxylic acids react very easily with metal ions to form salts which are mostly insoluble in DMF. Such reactions occur not only in DMF but also in DMSO; when sodium ion was titrated with EDTA

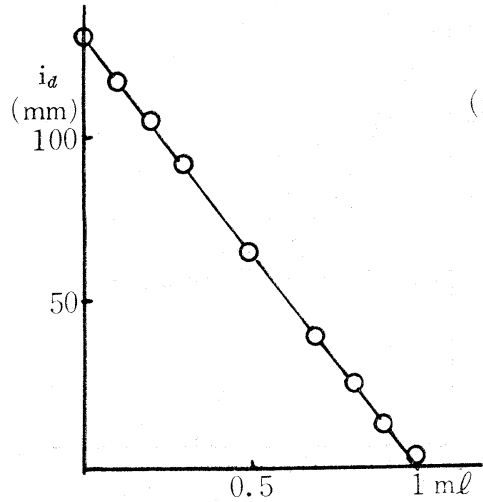

(A)

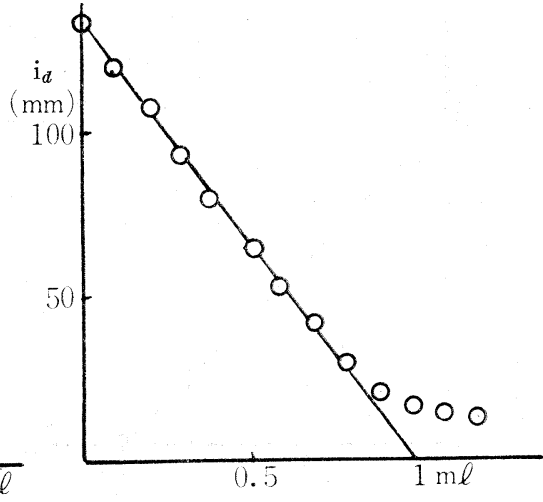

(B)

Fig. 5. Amperometric titration curves in DMF.

(A) : $10 \mathrm{ml}$ of $0.004 M \mathrm{Na}^{+}$containing $0.1 \mathrm{MEt}_{4} \mathrm{NGlO}_{4}$ was titrated with $0.02 M\left(\mathrm{Et}_{4} \mathrm{~N}\right)_{2}$-oxalate solution.

(B) : $10 \mathrm{ml}$ of $0.004 M \mathrm{Na}^{+}$containing $0.1 \mathrm{MEt}_{4} \mathrm{NClO}_{4}$ was titrated with $0.02 M\left(\mathrm{Et}_{4} \mathrm{~N}\right)_{2}$-phthalate solution. 
Table 2. Half-wave potentials of metal ions with tetraethylammonium carboxylate in DMF

\begin{tabular}{c|c|c|c|c}
\hline $\begin{array}{c}\text { Metal } \\
\text { ion }\end{array}$ & \multicolumn{3}{|c}{$E_{1 / 2}, \mathrm{~V}$ vs. S.C.E. } \\
& simple ion. & salicylate & benzoate & acetate \\
\hline $\mathrm{Na}^{+}$ & -2.02 & -2.04 & -2.05 & -2.06 \\
$\mathrm{Ba}^{++}$ & -2.03 & -2.04 & -2.27 & $\mathrm{NR}$ \\
$\mathrm{Zn}^{++}$ & -0.97 & -1.23 & $-2.0^{*}$ & $-2.1^{*}$ \\
$\mathrm{Cd}^{++}$ & -0.57 & -0.74 & $-1.65^{* *}$ & $-1.73^{* *}$ \\
$\mathrm{~Pb}^{++}$ & -0.41 & -0.55 & $-1.05^{* *}$ & $-1.13^{* *}$ \\
\hline
\end{tabular}

$1 \mathrm{~m} M$ metal ion $+5 \mathrm{~m} M$ carboxylate in $0.1 M \mathrm{Et}_{4} \mathrm{NGlO}_{4}$ at $25^{\circ} \mathrm{C}$

NR : Not reduced until $-2.7 \mathrm{~V}$

* : Start potential of the wave

** : Irreversible wave

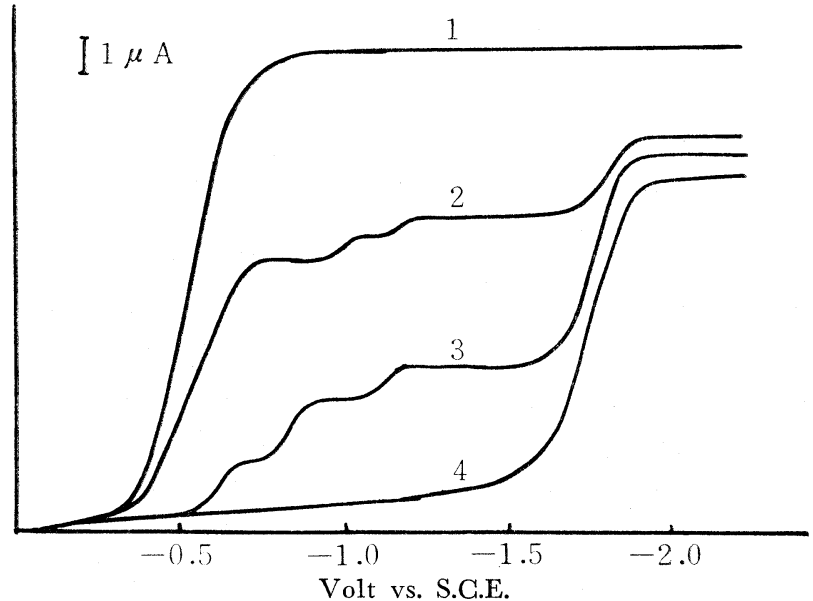

Fig. 6. Polarograms of $\mathrm{Cd}^{++}$in $\mathrm{DMF}$ solutions containing various concns. of acetate ion. $1 \mathrm{mM} \mathrm{Gd}+$ in $0.1 M \mathrm{Et}_{4} \mathrm{NGlO}_{4}$.

Acetate ion concn. : curve $1,0 \mathrm{~m} M ; 2,1 \mathrm{~m} M ; 3,2 \mathrm{~m} M ; 4,4 \mathrm{~m} M$.

anion or oxalate ion in DMSO, similar results as in DMF were obtained. But no quantitative relations could be obtained between the dissociation properties of the acids and their reactivities with metal ions; probably because of the effects of small amount of water and other impurities.

There have been reported a large number of works regarding the polarography in aprotic solvents and most of them had been carried out in unbuffered conditions. It is obvious that some of these investigations should be carried out in buffered conditions, but a difficulty arises in taking the influence of acid anions to metal ions into consideration. Even alkali metal ions react with anions of weak acids to form salts which are slightly dissociated even in a extremely dilute solutions.

\section{Acknowledgement}

The author expresses his deep gratitude to Professor Taitiro Fujinaga of Kyoto University for his kind guidance and encouragement and also to Dr. Kosuke Izutsu for his helpful suggestions and discussions throughout this work. 


\title{
References
}

1) H.E. Zaug and A.D. Shaufer, Anal. Chem. 36, 2121(1964)

2) J.E. Prue and P.J. Sherrington, Trans. Faraday Soc. 57, 1795 (1961)

3) D.L. McMaster, R.B. Dunlap, J.R. Kuempel, L.W. Kreider and T.R. Shearer, Anal. Chem. 39, 103 (1967)

4) K. Takaoka, Rev. Polarogr. 14, 63 (1966)

5) G.D. Ritchie and G.H. Megerle, J. Amer. Chem. Soc. 89, 1447 (1966)

6) C. Yosimura, H. Hara and K. Tamura, Japan Analyst 18, 689 (1968)

7) M.v. Stackerberg and H.v. Freyhold, Z. Elektrochem. 46, 120 (1940)

DMF 中に打けるEDTA 及び有機酸と金属イオンとの反応に

関するポーラログラフ的研究

\author{
文 寿 賛 \\ 京都大学理学部化学教室(京都市左京区北白川)
}

DMF 中における EDTA 及ご色々な有機酸と金属 イオンとの反応をポーラログラフ的方法で調べた 結 果，EDTA は金属イオンと反応としてキレートを形 成する前漠醮溶性の沈澱を生成し，アルカリ金属イオ ンとは4：1の比で結合し，アルカリ土類および他の 二価の金属イオンとは $4: 2$, また鉄(III)，インジウ ム(III)のような三価の金属イオンとは 4：3の比で結
合する。過剩の EDTA を加えると沈潵は溶け，生成 する金属キレートは水溶液中のそれより安定であり， 鉄(III)，銅(II)，ルビジウム（I )及びセシウム ( I ) 以 外は溶媒が還元されるまで還元波を示さなかった。こ のEDTA の挙動をシュウ酸, マロン酸, コハク酸, フマル酸, 酢酸, 安息香酸及びサリチル酸等と比較検 討した。 